\title{
Relations between Government Researchers and Academics
}

\section{ROGER TARLING}

Professor of Social Research, University of Surrey and former Head of the Home Office Research and Planning Unit

\begin{abstract}
Relations between government researchers in the Home Office and the Ministry of Justice and academics, often undertaking contract research on behalf of both departments, are at a low ebb. This state of affairs is not in the interest of either party or good for the debate on crime and criminal justice. The article suggests ways in which the rifts might be healed including more openness and transparency on behalf of government and the adoption of and adherence to principles to ensure the reputation of government sponsored research.
\end{abstract}

Keywords: research; policy; Home Office Research Unit (HORU); government social research

Along with many former colleagues I took part in a discussion of the formation and development of the Home Office Research Unit (HORU), which is to be available as an oral history (on the Centre for Contemporary British History website at: http://www.cchb.ac.uk). This opportunity to reflect on the past occurred at a time when I was becoming increasingly aware of the growing disillusionment of many leading criminologists with the scope and management of research funded by the Home Office and Ministry of Justice. I am not sure that much has changed in the 25 years since I last wrote in this journal on the nature of the relationship between research and policy (Tarling 1986) except, perhaps, an increase in the evaluation of policy initiatives and programme interventions (something I anticipated in the article). Research continues to be an important ingredient in policy development, through informing public opinion and changing the climate of debate, even if its contribution is indirect. Regrettably, what appears to have changed is the nature and function of the researchers in the Home Office and the Ministry of Justice and their engagement with the wider, mainly academic, research community. This article draws on the author's own experience and the published reflections of other previous senior Home Office researchers to assess the institutional factors which underpin a positive and transparent relationship between government researchers and the wider academic and research community.

I certainly would not wish to glorify the past or appear nostalgic, but, nevertheless, there were practices then that I think would be of value today. Tensions have always existed between research and policy, and always will. HORU was established in 1957 and its first head, Tom Lodge, reflecting on its early days, wrote: 'that to preserve scientific objectivity while acting as a servant of the Secretary of State has never been easy ...' (Lodge 1974, p.22). Leslie Wilkins, the deputy head of HORU in those early days would, perhaps, have regarded this as a gross understatement. Wilkins's experiences of ministerial interference led to his lifelong view that research in the Civil Service should be organised to serve parliament rather than the government of the day and thereby not under direct ministerial oversight (Wilkins 2001).

Subsequent heads of research at the Home Office, including myself, ${ }^{1}$ would concur with Lodge's statement, and could recount periods of great tension when 
research findings sat uncomfortably with directions in policy. In my case, my research on the incapacitation effects of imprisonment (Brody and Tarling 1980; Tarling 1993) was widely cited by the media as disproving Michael Howard's (the then Home Secretary) view that 'prison works'. Notwithstanding the fact that Research and Planning Unit staff like myself challenged government policy (and a further example during my time was Fields's (1990) research on the relationship between crime and the state of the economy), government research has always been viewed with some suspicion by academics who felt that Home Office reports were inevitably vetted and massaged by ministers before publication. As research has increasingly been contracted out to academics and other organisations, many will have personal experiences to reinforce those suspicions.

Maintaining the integrity and reputation of government research was a major role of senior management within the Unit, and this was achieved by establishing a set of principles, as detailed below, and fiercely defending them (see Clarke and Cornish 1983; Cornish and Clarke 1987; Croft 1977, 1980a, 1980b, 1981, 2005; Tarling 1986).

To ensure and demonstrate integrity, it was essential to engage and consult with all stakeholders, and to be open and transparent. Internally this meant discussions with officials in policy departments in order to identify and prioritise research need and to obtain ministerial endorsement for the resulting programme. In parallel, the outside research community would be invited to express its views at an annual conference suitably timed within the 'research cycle'.

Publishing the annual Research Programme made public what research was in train and what was planned (it also enabled me to compare, and reflect upon, changes in the scope of research between 1973 and 1985: Tarling (1986)). As well as being an audit of the Unit, it facilitated accountability in that anyone could enquire about progress of any aspect of the programme, including whether, or when, a report was to be published. As an example of this accountability, in my last years in the Home Office (circa 1994-96) the Guardian newspaper was suspicious that the then Home Secretary, Michael Howard, was delaying and suppressing the publication of research. In order to placate the newspaper I had to send the editor a three-monthly update on progress of all our internal and external projects. The Research Programme has not been published since 1996.

Of primary importance was to ensure that all research was published, and this was prominently and clearly stated at the beginning of the published annual Research Programme under the heading 'The Requirement to Publish':

The most visible part of the Unit's work is new published research. . . . The research is published so that results can become part of the public debate and be usable in Parliament. Publication also exposes research to public scrutiny and allows its quality to be assessed. There is a standing commitment, endorsed by successive Home Secretaries since 1957, to publish all results of substantive new research. Because of this policy the reliability and validity of Home Office research is rarely, if ever, questioned. The Unit is proud of its national and international reputation as a source of unbiased findings.

The continual professional engagement between government researchers and academics, whether by collaborating on research and scientific papers, or by government researchers presenting papers at conferences, were further means of ensuring quality. Scrutiny, discourse and debate with one's peers are the foundations of scientific inquiry. Whilst being fully engaged, the Unit did not seek to use its 
unique position and greater resources in order to exert undue influence on the development of criminology as an academic discipline. Mary Tuck, my predecessor as head of the Unit, would take every opportunity to tell an audience that we should 'let a thousand flowers bloom'. And John Croft, a former head of the Unit, neatly summed up the Unit's wider relationship with the academic community when he said that '[the Unit] has always recognised the desirability of stimulating independent scientific research on Home Office subjects' (Croft 1980b, p.4).

The Unit was proud of its national and international reputation for innovative, high-quality research (as the above quotation from the Research Programme document shows) and continually sought to maintain its standing. Its reputation strengthened the Unit's hand in internal negotiations but also helped enhance the public image of the Home Office, which was seen to be open and receptive to evidence. Internally, the Unit's role was, perhaps, best summed up by the phrase of Sir Brian Cubbon, Permanent Secretary at the Home Office (1978-85) that it should act 'as the gadfly on the dozing body politic' of the Home Office. Additionally, critical dialogue with external researchers added to that reputation, as it testified that the Unit was fully engaged in scientific debate. However, the benefits that a degree of independence and open engagement brought were not always immediately obvious to incoming ministers, or at times when tensions between research and policy were most acute. Ministers had to be persuaded that the long-term gains far outweighed shortterm losses. This message was often difficult to get across due to the fact that ministers did not expect to be at the Home Office for long and did not want their short tenure tarnished in any way.

Unlike Walters (2008), who calls for a boycott and disengagement by academics from government-sponsored research, I believe it to be in the national interest to have a vibrant, confident and authoritative in-house research capability, to undertake and commission studies that add to our understanding of crime and criminal justice. Moreover, researchers within government play a vital role, both in shaping research agendas and in feeding the findings of research into the heart of policy discussions. It is not in anyone's interest if the reputation of government research falls or is called into question. It saddens me to read outside researchers complaining of Home Office or Ministry of Justice's unnecessary obstruction of legitimate research endeavour, delays in publishing research or failure to meet contractual obligations (for example, Hope 2004, 2008; Morgan and Hough 2007; Raynor 2004, 2008; Walters 2008) - and many more have expressed their complaints orally; some going so far as to foreswear never working with government again. Without the alliance between government researchers and an independent research community, government research becomes an easy target for critics whose motives are malevolent or selfserving. It is no surprise to me, for example, that crime and criminal justice statistics (which in this country are the equal of, if not better than, those produced in any other country of the world) have come under so much ill-informed criticism.

It may be that declining relations are simply the inevitable by-product of the widely-discussed 'government by spin' and a disillusionment with New Labour, who promised to put evidence at the heart of policy making but who ended up - in the view of many - giving more weight to dogma, the media and public opinion. But I, and many, see other factors contributing. Some link worsening relations to the fact that many research contract managers have no (or very limited) actual experience of conducting research (it was once a HORU axiom that researchers split their time between conducting research and managing external projects) and do not see themselves as criminologists. Others point to the high turnover of government 
research staff, which allows little scope for building durable and trusting relationships with leading criminologists. A third explanation is that a critical watershed was reached when the Research Development and Statistics Directorate (RDS - as HORU subsequently became) ceased to exercise full control over the Home Office research budget (evaluating competing internal bids for funds through a series of research committees) and, instead, moved primarily to an emasculated role of simply commissioning research funded directly by policy and implementation teams. This, it is argued, inevitably led funders - particularly in an era increasingly characterised by evaluative research, where evidence-led principles indicated findings could make or break initiatives - to feel that they had an absolute right to influence research findings 'they had paid for'. This was also seen as the final step in separating customers from contractors (first mooted by Rothschild - although it is not always remembered that social research was explicitly excluded from the Rothschild (1971) 'customercontractor' principle).

Unfortunately, a response has been to be dismissive of the contribution of academic criminologists (see Wiles 2002). This stance ignores the different perspective that researchers bring, if only by drawing on their direct experience of the world beyond Whitehall, thereby providing a palliative to the other inputs to debate, namely the scripted presentations from practitioners and other groups with a vested interest in the outcome of policy deliberations.

Another reaction of RDS staff has been overly defensive, emphasising their role as contract managers rather than in partners 'seeking after knowledge' (Croft 1980b). But even if this is so, their interpretation of their role in a customer-contractor relationship is narrow or misguided. I am reminded of the point made by the procurement lecturer at the then Civil Service College when I arranged courses for social researchers in the late 1990s. His message was that a contract places obligations on all parties to a contract and all parties had to honour the terms of the contract. Furthermore, a contract could only be amended by negotiation and mutual agreement; it was not for one party to disregard the other and amend the terms of the contract as they wished - a complaint voiced by many contractors.

In addition to being governed by the terms of the contract, government researchers should also be guided by the ethics of the profession in the same way as any other social researcher; and perhaps more so as they arbitrate in the dispersal of not insignificant sums of public money. As a member of the initial group drafting the British Society of Criminology's Ethical Guide, after inclusion of passages highlighting researchers' responsibilities to funders, I was keen to assert that funders also had professional and ethical obligations. The following sentence was added:

In turn, it is hoped that funding bodies/sponsors will recognise that intellectual and professional freedom is of paramount importance and that they will seek to ensure that the dissemination of research findings is not unnecessarily delayed or obstructed because of considerations unrelated to the quality of the research.

These sentiments are also embodied in the Government Social Research's (GSR) own Code of Conduct (Government Social Research 2009) which states:

In all aspects of their work GSR members must act to maintain the integrity of the Government Social Research profession . . . and ... GSR members must act with honesty and fairness in dealings with colleagues and contractors. 
More recently, GSR has formulated guidance on the publication of government sponsored research (Government Social Research 2010). This states that reports should be published within twelve weeks of 'agreeing the final draft'. This goes some way to alleviating the delays that many of us have experienced.

Unfortunately, it is often 'agreeing the final draft' that proves contentious and is the source of the suspicions of manipulation of results to fit preset policy agendas. It is not uncommon for contractors to receive sequentially half a dozen different (often contradictory) sets of comments. This suggests to me a lack of authority on the part of Home Office and Ministry of Justice researchers who seem unable to adjudicate on various competing views within the department. It is only the objectivity and quality of the research that should be reviewed.

I established GSR in 1993 in order to provide collective strength to maintain principles for government-sponsored research. What is needed now is leadership within the Home Office and the Ministry of Justice to promulgate and defend those principles; to engage more openly, to become more transparent and accountable by publishing the research programme and to set and adhere to procedural standards. Learning from the experience of all parties in these crucial relationships - policy maker and government researcher on the one hand, and government researcher and academic/external researcher on the other - is critically important: for it is by active dialogue that any widening rifts can be bridged. And there are one or two encouraging signs in that the Ministry of Justice has recently held an open meeting about improving its ways of working with the outside research community. However, if those rifts cannot be bridged, consideration may also need to be given to whether setting up some additional formal structure akin to the UK Statistics Authority (a nonministerial body accountable to parliament, whose function is to provide independent scrutiny of all official statistics) would be helpful to ensure that the GSR principles are adhered to, in order to ensure the reputation of government-sponsored research.

\section{Note}

${ }^{1}$ I was head of the Home Office Research and Planning Unit from 1989 to 1996 and deputy head from 1985 to 1989.

\section{References}

Brody, S. and Tarling, R. (1980) Taking Offenders out of Circulation (Home Office Research Study No. 64), London: HMSO.

Clarke, R.V.G. and Cornish, D.B. (1983) Crime Control in Britain: A Review of Policy Research, Albany, NY.: SUNY Press.

Cornish, D.B. and Clarke, R.V.G. (1987) 'Social science in government: the case of the Home Office Research and Planning Unit’, in: M. Bulmer (Ed.), Social Science Research and Government, Cambridge: Cambridge University Press.

Croft, J. (1977) Research in Criminal Justice (Home Office Research Study No. 44), London: HMSO.

Croft, J. (1980a) Research and Criminal Policy (Home Office Research Study No. 59), London: HMSO.

Croft, J. (1980b) 'The universities and the Home Office', Research Bulletin No. 9, London: Home Office Research and Statistics Directorate.

Croft, J. (1981) Managing Criminological Research (Home Office Research Study No. 69), London: HMSO.

Croft, J. (2005) 'The hunting of the snark: reflections on a half century of crime', Political Quarterly, 76(1), 114-23. 
Field, S. (1990) Trends in Crime and their Interpretation (Home Office Research Study No. 119), London: HMSO.

Government Social Research (2009) GSR Code. Available at:

http://www.civilservice.gov.uk/my-civil-service/networks/professional/gsr (accessed

18 November 2010).

Government Social Research (2010) Publishing Research in Government: GSR

Publication Guidance. Available at: http://www.civilservice.gov.uk/my-civil-

service/networks/professional/gsr (accessed 29 December 2010).

Hope, T. (2004) 'Pretend it works: evidence and governance in the evaluation of the

Reducing Burglary Initiative', Criminal Justice, 4(3), 287-308.

Hope, T. (2008) 'A firing squad to shoot the messenger: Home Office peer review

research', in: W. McMahon (Ed.), Critical Thinking about the Uses of Research,

London: Centre for Crime and Justice Studies. Available at:

http://www.crimeandjustice.org.uk (accessed 23 October 2010)

Lodge, T.S. (1974) 'The founding of the Home Office Research Unit', in: R. Hood

(Ed.), Crime, Criminology and Public Policy, London: Heinemann.

Morgan, R. and Hough, M. (2007) 'The politics of criminological research', in: R.D.

King and E. Wincup (Eds.), Doing Research on Crime and Justice, 2nd edn, Oxford:

Oxford University Press.

Raynor, P. (2004) 'The probation service pathfinders', Criminal Justice, 4(3), 309-25.

Raynor, P. (2008) 'Community penalties and Home Office research', Criminology and Criminal Justice, 8(1), 73-87. Rothschild, Lord (1971) A Framework for

Government Research and Development, Cmnd.

4814. Tarling, R. (1986) 'Research, politics and criminal justice', Howard Journal, 25, 112-17. Tarling, R. (1993) Analysing Offending, London: HMSO. Walters, R. (2008)

'Government manipulation of criminological knowledge and policies of deceit', in:

W. McMahon (Ed.), Critical Thinking about the Uses of Research, London: Centre for Crime and Justice Studies. Available at: http://www.crimeandjustice.org.uk (accessed 23 October 2010).

Wiles, P. (2002) 'Criminology in the 21st century: public good or private interest?

The Sir John Barry Memorial Lecture', Australian and New Zealand Journal of Criminology, 35, 238-52.

Wilkins, L.T. (2001) Unofficial Aspects of a Life in Policy Research, Cambridge: published posthumously by Leslie Wilkins's family. 